\title{
The pan-erbB tyrosine kinase inhibitor CI-1033 inhibits human esophageal cancer cells in vitro and in vivo
}

\author{
E. AKO, Y. YAMASHITA, M. OHIRA, M. YAMAZAKI, T. HORI, N. KUBO, T. SAWADA and K. HIRAKAWA \\ Department of Surgical Oncology, Osaka City University Graduate School of Medicine, \\ 1-4-3 Asahi-machi, Abeno-ku, Osaka 545-8585, Japan
}

Received November 17, 2006; Accepted December 21, 2006

\begin{abstract}
The epidermal growth factor receptor (EGFR) is a member of the EGFR family of receptors. EGFR and other members of the EGFR family have been shown to play significant roles in human cancer cell proliferation and therefore present important molecular targets for the treatment of cancer. The purpose of this study was to examine the effect of the pan-erbB tyrosine kinase inhibitor CI-1033 against esophageal squamous cell carcinoma in vitro and in vivo. We selected 4 human esophageal squamous cell carcinoma cell lines (TT, TE2, TE6, and TE10), and determined their expression of EGFR and HER2. We examined the ability of CI-1033 to inhibit cell growth in vitro and in vivo. EGFR and HER2 were overexpressed in all 4 esophageal cancer cells. We found that CI-1033 could inhibit the growth of esophageal cancer cell lines in a dose-dependent manner with the inhibition of phosphorylation of both MAPK and AKT. The oral administration of CI-1033 exerted a significant antitumor effect on esophageal cancer tumors in athymic nude mice. Our results suggest that CI-1033 effectively inhibits the growth of esophageal squamous cell carcinoma which co-expresses both EGFR and HER2 with the inhibition of phosphorylation of both MAPK and AKT. Furthermore, in vivo animal studies of CI-1033 suggest that CI-1033 holds significant clinical potential in esophageal cancer.
\end{abstract}

\section{Introduction}

Esophageal cancer is one of the most lethal cancers and the 5 -year survival rate of patients diagnosed with esophageal cancer is approximately $23 \%$ to $50 \%$, even after complete resection with lymph node dissection (1-6). For esophageal cancers, comprehensive treatment with chemotherapy and/or

Correspondence to: Dr Yoshito Yamashita, Department of Surgical Oncology, Osaka City University Graduate School of Medicine, 1-4-3 Asahi-machi, Abeno-ku, Osaka 545-8585, Japan

E-mail: helji@med.osaka-cu.ac.jp

Key words: CI-1033, esophageal cancer, tyrosine kinase inhibitor, epidermal growth factor receptor, HER2 radiotherapy is performed as widely as surgical treatment. Chemoradiotherapy has a significant effect against esophageal cancer, but does not always yield a complete response $(7,8)$. Development of new therapies that would provide more effective responses for a larger number of patients is clearly needed for the treatment of human esophageal cancer.

The epidermal growth factor receptor (EGFR) (also known as c-erbB1/HER1), c-erb2 (HER2/neu), c-erbB3 (HER3) and c-erbB4 (HER4) are members of the EGFR superfamily and play a key role in cancer development and progression. EGFR and other EGFR family members become activated by formation of EGFR/EGFR homodimers and EGFR/HER2 heterodimers after ligands, such as transforming growth factor- $\alpha$ or EGF, bind to EGFR $(9,10)$. These events lead to the recruitment and phosphorylation of several intracellular substrates, leading to mitogenic signaling and other cellular activities. Two important signaling routes that are activated by EGFR involve the Ras-Raf-MAPK and the PI3K-AKT pathways, which are implicated in cell proliferation, survival and gene expression (11).

The EGFR family is overexpressed in a significant proportion of human cancers such as breast, lung, head and neck, glioblastomas and thyroid, and have been shown to play an important role in human cancer cell proliferation (12-17). In esophageal squamous cell carcinoma, there is frequent overexpression of EGFR and a correlation between EGFR expression and prognosis has also been reported $(18,19)$. In addition, HER2 expression is detectable in a variety of esophageal tumors (20). Our previous study found that co-expression of EGFR and HER2 was observed in approximately $90 \%$ of primary human esophageal squamous cell carcinoma. Therefore, the EGFR family is an attractive candidate target for cancer therapy and many different EGFRtargeted molecular treatments have been attempted, such as anti-receptor monoclonal antibodies, anti-ligand monoclonal antibodies, ligand-toxin conjugates, scFv-toxin conjugates, ligand-genistein conjugates and tyrosine kinase inhibitors (21). Several studies and our previous study suggest that combined treatment with drugs that target EGFR and HER2 might result in efficient inhibition of tumor growth in breast cancer, head and neck cancer, and epidermoid and esophageal carcinomas $(22,23)$.

CI-1033 (formerly known as PD183805) is an orally available pan-erbB tyrosine kinase inhibitor that irreversibly inhibits signaling from all members of the EGFR family 
(24-26). Several studies have shown that CI-1033 inhibits the growth of cancer cells including glioblastoma, bile duct, breast and colon cancer $(24,26-29)$. Treatment of athymic nude mice bearing xenografts of various tumors with CI1033 results in highly significant suppression of tumor growth. In this study, we examined the effects of CI-1033 on cell proliferation, cell survival and signal transduction in esophageal squamous cell carcinoma cells that express EGFR and HER2.

\section{Materials and methods}

Reagents. The pan-erbB tyrosine kinase inhibitor CI-1033 was kindly provided by Pfizer Inc. (Groton, CT).

Cell lines and cell cultures. TT human esophageal squamous cell carcinoma cells were obtained from the Health Science Research Resources Bank (Osaka, Japan). TE2, TE6 and TE10 human esophageal squamous cell carcinoma cells were obtained from the Tohoku University Graduate School of Medicine. All cell lines were maintained as monolayers at $37^{\circ} \mathrm{C}$ and in a humidified atmosphere of $5 \% \mathrm{CO}_{2}$ in the presence of Dulbecco's modified Eagle's medium (DMEM; Bioproducts, Walkersville, MD) or RPMI-1640 (SigmaAldrich, St. Louis, MO) supplemented with $10 \%$ fetal bovine serum (FBS; Gibco, Grand Island, NY), $100 \mathrm{IU} / \mathrm{ml}$ of penicillin (ICN Biomedicals, Costa Mesa, CA), $100 \mu \mathrm{g} / \mathrm{ml}$ of streptomycin (ICN Biomedicals, Aurora, $\mathrm{OH}$ ), and $0.5 \mathrm{mM}$ of sodium pyruvate (Bioproducts).

Care of animals. Female athymic BALB/c nude mice, 4 weeks of age, were obtained from Crea Japan, Inc., Tokyo, Japan. The mice were kept in sterilized cages equipped with an air filter and sterile bedding materials and fed with sterilized water and food throughout the study. The research complied with national legislation and with company policy on the care and use of animals and with related codes of practice.

Reverse transcription-polymerase chain reaction. We used human EGFR and HER2 primer kits (Maxim Biotech, Inc., San Francisco, CA) to confirm the expression of EGFR and HER2 in the esophageal cancer cells. RNA was extracted using Trizol (Life Technologies, Inc., Gaithersburg, MD, USA) according to the instructions of the manufacturer. Total RNA (1 ng) was reverse-transcribed in $20 \mu 1$ of reaction buffer containing $1 \mu \mathrm{l}$ of oligo dT primer, $4 \mu 1$ of $5 \mathrm{X}$ RNA PCR buffer, $1 \mu \mathrm{l}$ of $10 \mathrm{mM}$ dNTPs, $2 \mu \mathrm{l}$ of $0.1 \mathrm{M}$ DTT, $0.5 \mu \mathrm{l}$ of RNA guard (Amersham Pharmacia Biotech, Buckinghamshire, UK) and $1 \mu \mathrm{l}$ of Moloney murine leukemia virus reverse transcriptase (Life Technologies). The cDNA samples were amplified in $20 \mu 1$ of a PCR reaction mixture with each primer set and Taq-polymerase (AmpliTaq Gold, Applied Biosystems, Tokyo, Japan). The primers used for EGFR were 5'-CGTTGCTGGCTGCGCTCTG-3' and 5'AGCCACCTCCTGGATGGTC-3' (product size, $221 \mathrm{bp}$ ); and for HER2, 5'-GCTGGCTCCGATGTATTTGATGGT-3' and 5'-GTTCTCTGCCGTAGGTGTCCCTTT-3' (product size, 495 bp). As a control, we amplified GAPDH by RTPCR with the following oligonucleotide primers: 5'-GTCAA
CGGATTTGGTCTGTATT-3' and 5'-AGTCTTCTGGGT GGCAGTGAT-3' (product size, 560 bp).

Cell proliferation assay. Inhibition of the growth of esophageal cancer cells in vitro was determined by counting cell number. Cells $\left(1 \times 10^{4}\right)$ were seeded in each well of a 24 -well plastic culture plate and left overnight in DMEM or RPMI-1640 supplemented with $10 \%$ FBS. The next morning, the cells were treated with the indicated concentrations of CI-1033 (0.1-5.0 nM) for several periods (1, 3, 5 and 7 days). After the treatment, cells were counted with a Coulter Counter (Beckman Coulter, Miami, FL). Triplicate wells were treated in each experiment. The percent of cell proliferation was calculated by this formula: treatment cell number/control cell number x100 at each time.

Phosphorylation assay. We determined an indirect measure of kinase activity in the cells by the detection of phosphorylated MAPK and AKT (p-MAPK and p-AKT) on immunoblots. Cells were incubated for $24 \mathrm{~h}$ and CI-1033 $(1.0 \mathrm{nM})$ was added for a total drug exposure time of $72 \mathrm{~h}$ for the treatment regimen. After the treatment, the cells were lysed in $100 \mu 1$ of ice-cold lysis buffer, and the protein was then extracted by centrifugation for $5 \mathrm{~min}$ at $12,000 \mathrm{rpm}$ at $4^{\circ} \mathrm{C}$. The protein concentration was measured and total protein $(40 \mu \mathrm{g})$ from each sample was electrophoresed on a $12.5 \%$ polyacrylamide gel and transferred to a nitrocellulose membrane (Millipore Corporation, Billerica, MA). The membrane was then blocked for $1 \mathrm{~h}$ in $5 \%$ skim milk at room temperature, and incubated overnight at $4^{\circ} \mathrm{C}$ with $\mathrm{p} 44 / 42$ MAPK, AKT, phospho-p44/42 MAPK and phospho-AKT (all from Cell Signaling Technology Inc., Beverly, MA; diluted 1:1000 in PBS). After the membrane was washed in $0.3 \%$ TBS-T (Tris buffer solution with Tween-20) three times for $5 \mathrm{~min}$ each at room temperature, it was incubated with anti-rabbit $\mathrm{IgG}$, peroxidase-linked species-specific whole antibody (Amersham Biosciences, Buckinghamshire, $\mathrm{UK})$ as a secondary antibody for $1 \mathrm{~h}$ at room temperature, and washed again 3 times in $0.3 \%$ TBS-T under the same conditions. Proteins were detected by ECL Western blotting detection reagents and Hyperfilm ECL (both from Amersham Biosciences).

Tumor growth studies. TT, TE6 or TE10 cells $\left(1 \times 10^{6}\right)$ were suspended in $100 \mu 1$ of PBS (phosphate buffered saline) and injected subcutaneously into nude mice. Approximately 6 weeks after injection, the tumor (1 cm in diameter) was resected aseptically and minced into $3-\mathrm{mm}^{3}$ pieces. Next, host mice were anesthetized with diethyl ether and a piece of tumor was implanted into the left flank of each mouse. The tumors were allowed to reach $30-100 \mathrm{~mm}^{3}$ in size (7 days after tumor implantation), and the mice were randomly divided into three groups of 6 animals each, and the treatment was initiated. Two groups of mice were treated orally with 2.5 or $10 \mathrm{mg} / \mathrm{kg}$ of CI-1033 dissolved in $100 \mu \mathrm{l}$ of PBS once a day on days 1-5 of each week for 5 weeks. A control group received oral PBS $(100 \mu 1)$ in the same manner. The mice were monitored daily for signs of toxicity. Body weight and tumor measurements were taken twice a week. The tumor volume was calculated by this formula: tumor volume = 


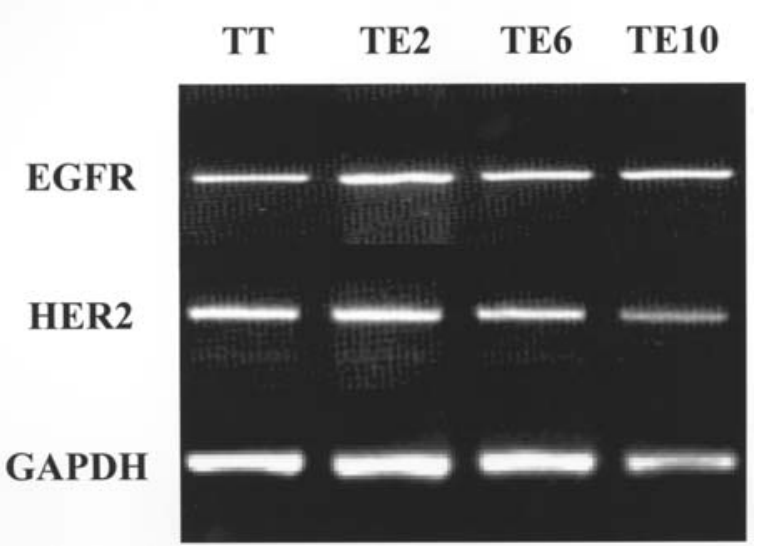

Figure 1. Expression of EGFR mRNA and HER2 mRNA in the esophageal squamous cell carcinoma cell lines TT, TE2, TE6 and TE10 was evaluated by RT-PCR. EGFR mRNA was detectable in all cell lines. HER2 mRNA was also detectable in all cell lines although the expression level in TE10 was lower than in the other cell lines.

length $\mathrm{x}$ width $2 / 2$, where length and width are the longer and shorter dimensions of the tumor, respectively.

Statistical analysis. Results are presented as the mean \pm standard deviation (SD) and taken from at least 4 independent determinations. Student's t-test was used for the statistical analysis, and a difference was considered significant at $\mathrm{p}<0.05$.

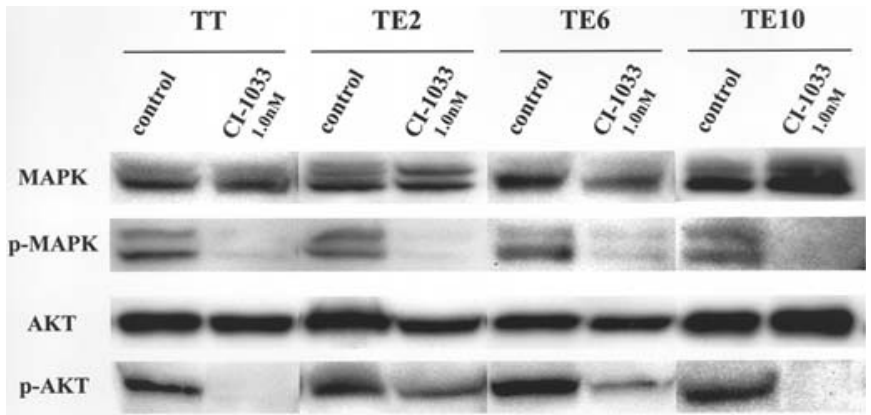

Figure 3. CI-1033 treatment affects the Ras/MAPK and PI3K/AKT pathways. We determined an indirect measure of kinase activity in cells by the detection of phosphorylated MAPK and AKT (p-MAPK and p-AKT) on immunoblots. Cells were incubated for $24 \mathrm{~h}$ and CI-1033 $(1.0 \mathrm{nM})$ was added for a total drug exposure time of $72 \mathrm{~h}$. The protein concentration was measured and total protein $(40 \mu \mathrm{g})$ from each sample was electrophoresed on a $12.5 \%$ polyacrylamide gel and transferred to a nitrocellulose membrane. The membranes were blotted with antibodies against MAPK, AKT, p-MAPK and p-AKT. CI1033 significantly inhibited the phosphorylation of MAPK in all cell lines, TT, TE2, TE6 and TE10. On the other hand, the phosphorylation of AKT was completely inhibited in the TT and TE10 cell lines but the inhibitory effect in TE2 and TE6 was weak.

\section{Results}

EGFR and HER2 expression in esophageal cancer cells. As shown in Fig. 1, expression of EGFR mRNA and HER2 mRNA in the esophageal cancer cell lines TT, TE2, TE6 and
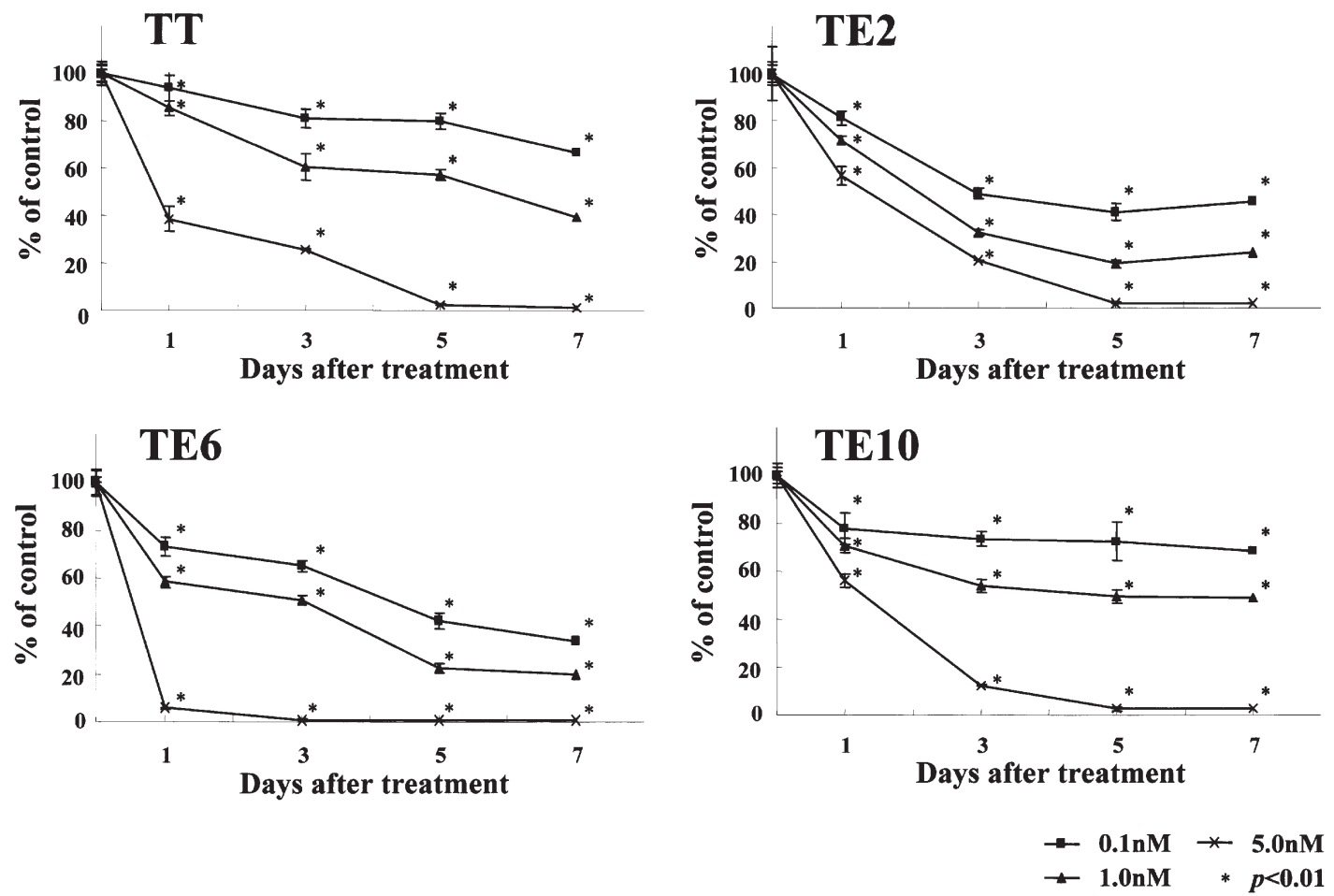

Figure 2. Inhibition of the growth of esophageal squamous cell carcinoma cell lines TT, TE2, TE6 and TE10 in vitro was determined by counting the cell number. Cells $\left(1 \times 10^{4}\right)$ were seeded into each well of a 24-well plastic culture plate and left overnight in DMEM or RPMI-1640 supplemented with $10 \%$ FBS. The cells were then treated with the indicated concentrations of CI-1033 (0.1-5.0 nM) for various times (1, 3, 5 and 7 days). After treatment, the cells were counted using a Coulter Counter. The percent of cell proliferation was calculated by this formula: treatment cell number/control cell number x100. After one day of treatment with CI-1033 (0.1-5.0 nM), significant inhibition of cell growth was observed in all cell lines at all concentrations of CI-1033 examined. The dose of CI-1033 required to inhibit cell growth was as low as $0.1 \mathrm{nM}$. An inhibitory effect of CI-1033 on cancer cell growth was dose- and time-dependent. 

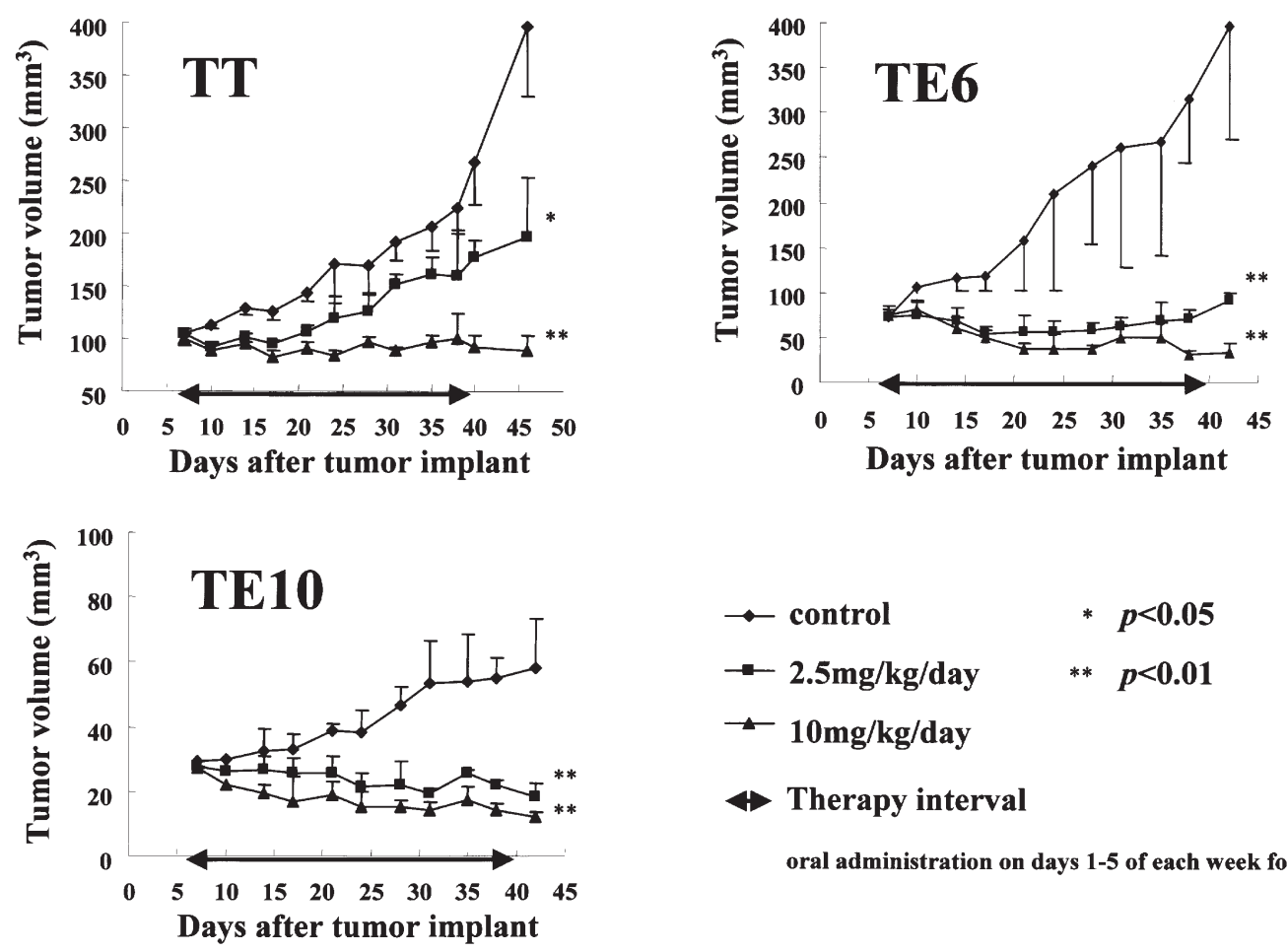

$\leftrightarrow$ Therapy interval

oral administration on days 1-5 of each week for 5 weeks

Figure 4. Growth of esophageal cancer s.c. xenografts in nude mice is inhibited by CI-1033. Esophageal squamous cell carcinoma tumors were established by implanting a 3- $\mathrm{mm}^{3}$ piece of tumor into the left flank of each mouse. Seven days after tumor implantation, two groups of mice were treated orally with 2.5 or $10 \mathrm{mg} / \mathrm{kg}$ of CI-1033 dissolved in $100 \mu 1$ of PBS once a day on days 1-5 of each week for 5 weeks. A control group received oral PBS (100 $\mu$ l) in the same manner. The oral administration of CI-1033 caused a marked growth inhibition of all tumors at the end of the 5-week treatment period with doses of 2.5 and $10 \mathrm{mg} / \mathrm{kg}$. This effect was dose-dependent. Complete inhibition of tumor growth was observed at the $2.5 \mathrm{mg} / \mathrm{kg} / \mathrm{day}$ dose against the TE6 and TE10 tumors and the $10 \mathrm{mg} / \mathrm{kg} / \mathrm{day}$ dose against the TT, TE6 and TE10 tumors $(p<0.01)$.

TE10 was evaluated by RT-PCR. EGFR mRNA was detectable in all cell lines. HER2 mRNA was also detectable in all cell lines although the expression level in TE10 was lower than in the other cell lines.

CI-1033 inhibition of esophageal cancer cell proliferation. The effect of CI-1033 on esophageal cancer cell proliferation was investigated in the TT, TE2, TE6 and TE10 cell lines (Fig. 2). After one day of treatment with CI-1033 (0.1-5.0 nM) significant inhibition of cell growth was observed in all cell lines at all concentrations of CI-1033 examined. The dose of CI-1033 required to inhibit the cell growth was as low as $0.1 \mathrm{nM}$. The inhibitory effect of CI-1033 on cancer cell growth was dose- and time-dependent.

Effect of CI-1033 on phosphorylation of MAPK and AKT. We evaluated the effects of CI-1033 on downstream intracellular signaling through the EGFR family members in the TT, TE2, TE6 and TE10 cell lines. Fig. 3 shows the result of Western blot analysis. CI-1033 significantly inhibited the phosphorylation of MAPK in all the cell lines, TT, TE2, TE6 and TE10. Alternatively, the phosphorylation of AKT was completely inhibited in the TT and TE10 cell lines but the inhibitory effect in TE2 and TE6 was weak.

Effect of CI-1033 treatment on the growth of xenografts in nude mice. We examined the effect of CI-1033 against xenografts of TT, TE6 and TE10 but not TE2 because it did not form a tumor in nude mice. As shown in Fig. 4, the oral administration of CI-1033 caused a marked growth inhibition of all tumors at the end of the 5-week treatment period. This effect was dose-dependent. Complete inhibition of tumor growth was observed at the $2.5 \mathrm{mg} / \mathrm{kg} /$ day dose in the TE6 and TE10 tumors and the $10 \mathrm{mg} / \mathrm{kg} /$ day dose in the TT, TE6 and TE10 tumors $(\mathrm{p}<0.01)$. No mouse died during this period. In all doses, there was $<10 \%$ weight loss in the treated mice for the duration of the treatment (data not shown). No increase in major toxicity such as superficial dermatitis, skin sores or diarrhea was observed in the multidose studies.

\section{Discussion}

The activity of the EGFR family is tightly controlled by positive and negative regulatory forces in normal cells $(30,31)$. However, many malignant cells have lost this ability and display aberrant signaling, leading to overexpression of EGFR family members, principally EGFR and HER2. The overexpression and activation of EGFR and HER2 result in a cascade of downstream substrate activation, leading to a number of processes important to cancer development and progression, including cell proliferation, apoptosis, angiogenesis, and metastasis. HER2 is the preferred dimerization partner for other members of the EGFR family, and heterodimerization with EGFR and HER2 generates the most potent intracellular signals $(9,10)$. There is rich crosstalk between EGFR and HER2 that regulates the cellular effects mediated by these receptors $(9,32-36)$. Therefore, it is reasonable to target both EGFR and HER2 in order to inhibit the proliferation 
of cancer cells stimulated by their signals. Recent studies have shown that dual EGFR-HER2 targeting with mAb or tyrosine kinase inhibitor results in enhanced inhibition of cancer cell proliferation expressing both EGFR and HER2 in breast, head and neck and pancreatic cancer (37-41). Simultaneous blockade of different molecular sites within the EGFR family network may diminish potential compensatory mechanisms by tumor cells compared with a single target approach against EGFR and HER2.

Junttila et al reported that erbB mRNA levels measured by RT-PCR closely correlated with protein levels in cancer cell lines (42). In this study, EGFR mRNA and HER2 mRNA were detectable in all 4 esophageal cancer cell lines by RTPCR and flow cytometric analysis showed almost the same result as RT-PCR (data not shown). This study and others have demonstrated that esophageal squamous cell carcinoma cells express higher levels of EGFR and HER2 compared with other types of malignant cells $(18,20)$. In addition, a correlation between EGFR expression and prognosis of esophageal cancer has also been reported (19). Therefore, this may suggest that targeting therapies against EGFR and HER2 may be promising for esophageal cancer. We demonstrated previously that the anti-EGFR mAb C225 could inhibit the growth of esophageal cancer cells. Furthermore, combined treatment with $\mathrm{C} 225$ and the antiHER 2 mAb trastuzumab induced a robust inhibition of esophageal cancer proliferation although trastuzumab alone did not inhibit the proliferation in vitro. In this study, we demonstrated a dramatic growth suppressive effect of CI1033 on esophageal cancer cells in vitro and in vivo.

CI-1033 is a potent pan-erbB tyrosine kinase inhibitor that inhibits signaling from all members of the EGFR family including EGFR and HER2. The expression of HER3 and HER4 in esophageal cancer has been reported but their role in cancer development and progression is not clear (43-45). A recent study demonstrated that the overexpression and/or activation of HER3 and HER4 correlated with poor tumor prognosis in breast cancer and other cancers (46). Blockade of HER3 and HER4 signaling by CI-1033 may also contribute to its anti-tumor effects on esophageal cancer cells.

There is growing evidence that signal transduction through the EGFR family has been shown to be mediated through two major pathways resulting in the activation of AKT and MAPK, which have both been associated with mitogenesis and cell survival (47). Nelson and Fry reported that CI-1033 significantly reduced the constitutively activated components of both pathways in human breast carcinomas (24). In this study, we have found that CI-1033 produced an almost complete reduction in the levels of MAPK phosphorylation in all 4 esophageal cancer cell lines and that of AKT in TT and TE10 cells. However, it did not completely inhibit the phosphorylation of AKT in the other 2 cell lines. The signaling pathways which induce apoptosis in cancer cells have been varied and tend to depend on the genetic background and origin of the cancer cell (48). Other growth factor receptors, such as FGF receptors, may be associated with the activation of the AKT signaling pathway in these cell lines (49). Nelson and Fry also demonstrated that p38 activation in the basal state of cancer cells is necessary for the induction of apoptosis by CI-1033 through its inhibition of the two major survival pathways (24). Esophageal cancer cells may exhibit highly activated p38 in the basal state although we have not verified this. Potential cancer therapies must not only inhibit cell growth in vitro but also must be able to inhibit tumor growth in the complex in vivo environment. Several researchers have reported that CI-1033 treatment of athymic nude mice bearing xenografts of epidermoid carcinoma, non-small cell lung carcinoma, glioblastoma, and breast and colon cancer results in highly significant suppression of tumor growth $(26,27,50)$. Our study showed that treatment with CI-1033 completely prevents the growth of esophageal squamous cell carcinoma xenografts. CI-1033 therapy for esophageal cancer may hold significant clinical potential because esophageal cancers simultaneously express higher levels of EGFR and HER2 compared with other malignancies.

CI-1033 treatment might induce potent adverse effects when used in patients. However, Slichenmyer et al reported that CI-1033's action appears to be highly specific for the EGFR family with no inhibitory activity against other protein kinases even at high concentrations, and such selectivity may explain the minimal toxicity observed in multidose animal studies (26). In addition, Mendelsohn and Baselga suggested that normal epithelial cells may be less susceptible than malignant cells to cytotoxicity from EGFR therapy because growth factors generally do not serve as survival factors for epithelial cells (51). In this study, adverse events such as diarrhea and skin rash were not observed in multidose studies in vivo.

Experimental data reported by Gieseg et al indicates that the combination of CI-1033 and cisplatin results in synergistic in vitro growth inhibition of the EGFR-overexpressing human squamous cell line A431 (25). Since cisplatin is one of the most active chemotherapeutic agents for the treatment of esophageal cancer, enhanced antitumor activity by the combination of this drug and CI-1033 may be observed in clinical trials. In addition, some studies indicate that CI-1033 has synergistic effects when combined with ionizing radiation in breast, colon cancer and bile duct carcinoma $(27,28,52)$. If CI-1033 is used in esophageal cancer therapy in the future, the concurrent use of other treatment strategies, such as chemoradiotherapy, should be included. In conclusion, this study has shown that the pan-erbB tyrosine kinase inhibitor CI-1033 effectively inhibits the growth of esophageal squamous cell carcinoma which co-expresses both EGFR and HER2 with the inhibition of phosphorylation of both MAPK and AKT. Furthermore, in vivo animal studies of CI-1033 suggest that CI-1033 holds significant clinical potential in esophageal cancer. Our results suggest that the antitumor effects of CI1033 might offer a new therapeutic approach in esophageal squamous cell carcinoma which simultaneously expresses EGFR and HER2.

\section{Acknowledgements}

Our study was supported in part by a Grant-in-Aid for the Osaka City University Medical Research Foundation. We also thank Mr. Donnie W. Owens (Pfizer Inc.) for providing CI-1033. 


\section{References}

1. Muller JM, Erasmi H, Stelzner M, Zieren U and Pichlmaier H: Surgical therapy of oesophageal carcinoma. Br J Surg 77: 845-857, 1990.

2. Watanabe $\mathrm{H}$, Kato $\mathrm{H}$ and Tachimori $\mathrm{Y}$ : Significance of extended systemic lymph node dissection for thoracic esophageal carcinoma in Japan. Recent Results Cancer Res 155: 123-133, 2000.

3. Peracchia A, Bonavina L, Ruol A and Stein H: Esophageal cancer: a European perspective. Recent Results Cancer Res 155: 119-122, 2000

4. Lerut T, Coosemans W, De Leyn P, Van Raemdonck D, Deneffe G and Decker G: Treatment of esophageal carcinoma. Chest 116: 463S-465S, 1999.

5. McManus K, Anikin V and McGuigan J: Total thoracic oesophagectomy for oesophageal carcinoma: has it been worth it? Eur J Cardiothorac Surg 16: 261-265, 1999.

6. Torres AJ, Sanchez-Pernaute A, Hernando F, Diez Valladares L, Gonzalez Lopez O, Perez Aguirre E, Suarez A and Balibrea JL: Two-field radical lymphadenectomy in the treatment of esophageal carcinoma. Dis Esophagus 12: 137-143, 1999.

7. Bosset JF, Gignoux M, Triboulet JP, Tiret E, Mantion G, Elias D, Lozach P, Ollier JC, Pavy JJ, Mercier M and Sahmoud T: Chemoradiotherapy followed by surgery compared with surgery alone in squamous-cell cancer of the esophagus. N Engl J Med 337: 161-167, 1997.

8. Herskovic A, Martz K, al-Sarraf M, Leichman L, Brindle J, Vaitkevicius V, Cooper J, Byhardt R, Davis L and Emami B: Combined chemotherapy and radiotherapy compared with radiotherapy alone in patients with cancer of the esophagus. $\mathrm{N}$ Engl J Med 326: 1593-1598, 1992.

9. Graus-Porta D, Beerli RR, Daly JM and Hynes NE: ErbB-2, the preferred heterodimerization partner of all ErbB receptors, is a mediator of lateral signaling. EMBO J 16: 1647-1655, 1997.

10. Karunagaran D, Tzahar E, Beerli RR, Chen X, Graus-Porta D, Ratzkin BJ, Seger R, Hynes NE and Yarden Y: ErbB-2 is a common auxiliary subunit of NDF and EGF receptors: implications for breast cancer. EMBO J 15: 254-264, 1996.

11. Yarden Y and Sliwkowski MX: Untangling the ErbB signalling network. Nat Rev Mol Cell Biol 2: 127-137, 2001

12. Nobuhara Y, Onoda N, Yamashita Y, Yamasaki M, Ogisawa K, Takashima T, Ishikawa $\mathrm{T}$ and Hirakawa K: Efficacy of epidermal growth factor receptor-targeted molecular therapy in anaplastic thyroid cancer cell lines. Br J Cancer 92: 1110-1116, 2005.

13. Schlegel J, Merdes A, Stumm G, Albert FK, Forsting M, Hynes N and Kiessling M: Amplification of the epidermal-growth-factorreceptor gene correlates with different growth behaviour in human glioblastoma. Int J Cancer 56: 72-77, 1994.

14. Kitagawa Y, Ueda M, Ando N, Ozawa S and Kitajima M: Effect of endogenous and exogenous EGF on the growth of EGF receptor-hyperproducing human squamous cell carcinoma implanted in nude mice. Br J Cancer 72: 865-868, 1995.

15. Pegram MD, Pauletti G and Slamon DJ: HER-2/neu as a predictive marker of response to breast cancer therapy. Breast Cancer Res Treat 52: 65-77, 1998.

16. Harris AL, Nicholson S, Sainsbury R, Wright C and Farndon J: Epidermal growth factor receptor and other oncogenes as prognostic markers. J Natl Cancer Inst Monogr: 181-187, 1992.

17. Nicholson S, Sainsbury JR, Halcrow P, Chambers P, Farndon JR and Harris AL: Expression of epidermal growth factor receptors associated with lack of response to endocrine therapy in recurrent breast cancer. Lancet 1: 182-185, 1989.

18. Itakura Y, Sasano H, Shiga C, Furukawa Y, Shiga K, Mori S and Nagura $\mathrm{H}$ : Epidermal growth factor receptor overexpression in esophageal carcinoma. An immunohistochemical study correlated with clinicopathologic findings and DNA amplification. Cancer 74: 795-804, 1994

19. Ozawa S, Ueda M, Ando N, Shimizu N and Abe O: Prognostic significance of epidermal growth factor receptor in esophageal squamous cell carcinomas. Cancer 63: 2169-2173, 1989.

20. Shiga K, Shiga C, Sasano H, Miyazaki S, Yamamoto T, Yamamoto M, Hayashi N, Nishihira T and Mori S: Expression of c-erbB-2 in human esophageal carcinoma cells: overexpression correlated with gene amplification or with GATA-3 transcription factor expression. Anticancer Res 13: 1293-1301, 1993.

21. Raymond E, Faivre S and Armand JP: Epidermal growth factor receptor tyrosine kinase as a target for anticancer therapy. Drugs 60 (suppl 1): 15-23, 2000.
22. Rusnak DW, Lackey K, Affleck K, Wood ER, Alligood KJ, Rhodes N, Keith BR, Murray DM, Knight WB, Mullin RJ and Gilmer TM: The effects of the novel, reversible epidermal growth factor receptor/ErbB-2 tyrosine kinase inhibitor, GW2016, on the growth of human normal and tumor-derived cell lines in vitro and in vivo. Mol Cancer Ther 1: 85-94, 2001.

23. Fry DW, Bridges AJ, Denny WA, Doherty A, Greis KD, Hicks JL, Hook KE, Keller PR, Leopold WR, Loo JA, McNamara DJ, Nelson JM, Sherwood V, Smaill JB, Trumpp-Kallmeyer S and Dobrusin EM: Specific, irreversible inactivation of the epidermal growth factor receptor and erbB2, by a new class of tyrosine kinase inhibitor. Proc Natl Acad Sci USA 95: 12022-12027, 1998.

24. Nelson JM and Fry DW: Akt, MAPK (Erk1/2), and p38 act in concert to promote apoptosis in response to ErbB receptor family inhibition. J Biol Chem 276: 14842-14847, 2001.

25. Gieseg MA, de Bock C, Ferguson LR and Denny WA: Evidence for epidermal growth factor receptor-enhanced chemosensitivity in combinations of cisplatin and the new irreversible tyrosine kinase inhibitor CI-1033. Anticancer Drugs 12: 683-690, 2001.

26. Slichenmyer WJ, Elliott WL and Fry DW: CI-1033, a pan-erbB tyrosine kinase inhibitor. Semin Oncol 28: 80-85, 2001.

27. Nyati MK, Maheshwari D, Hanasoge S, Sreekumar A, Rynkiewicz SD, Chinnaiyan AM, Leopold WR, Ethier SP and Lawrence TS: Radiosensitization by pan ErbB inhibitor CI-1033 in vitro and in vivo. Clin Cancer Res 10: 691-700, 2004.

28. Murakami M, Sasaki T, Yamasaki S, Kuwahara K, Miyata H and Chayama $\mathrm{K}$ : Induction of apoptosis by ionizing radiation and CI-1033 in HuCCT-1 cells. Biochem Biophys Res Commun 319: 114-119, 2004

29. Erlichman C, Boerner SA, Hallgren CG, Spieker R, Wang XY, James CD, Scheffer GL, Maliepaard M, Ross DD, Bible KC and Kaufmann SH: The HER tyrosine kinase inhibitor CI1033 enhances cytotoxicity of 7-ethyl-10-hydroxycamptothecin and topotecan by inhibiting breast cancer resistance proteinmediated drug efflux. Cancer Res 61: 739-748, 2001.

30. Hackel PO, Zwick E, Prenzel N and Ullrich A: Epidermal growth factor receptors: critical mediators of multiple receptor pathways. Curr Opin Cell Biol 11: 184-189, 1999.

31. Moghal $\mathrm{N}$ and Sternberg PW: Multiple positive and negative regulators of signaling by the EGF-receptor. Curr Opin Cell Biol 11: 190-196, 1999

32. Riese DJ II and Stern DF: Specificity within the EGF family/ErbB receptor family signaling network. Bioessays 20: 41-48, 1998.

33. Tzahar E, Pinkas-Kramarski R, Moyer JD, Klapper LN, Alroy I, Levkowitz G, Shelly M, Henis S, Eisenstein M, Ratzkin BJ, Sela M, Andrews GC and Yarden Y: Bivalence of EGF-like ligands drives the ErbB signaling network. EMBO J 16: 4938-4950, 1997.

34. Burke CL, Lemmon MA, Coren BA, Engelman DM and Stern DF: Dimerization of the p185neu transmembrane domain is necessary but not sufficient for transformation. Oncogene 14: 687-696, 1997.

35. Reese DM and Slamon DJ: HER-2/neu signal transduction in human breast and ovarian cancer. Stem Cells 15: 1-8, 1997.

36. Pinkas-Kramarski R, Soussan L, Waterman H, Levkowitz G, Alroy I, Klapper L, Lavi S, Seger R, Ratzkin BJ, Sela M and Yarden Y: Diversification of Neu differentiation factor and epidermal growth factor signaling by combinatorial receptor interactions. EMBO J 15: 2452-2467, 1996.

37. Janmaat ML, Kruyt FA, Rodriguez JA and Giaccone G Response to epidermal growth factor receptor inhibitors in nonsmall cell lung cancer cells: limited antiproliferative effects and absence of apoptosis associated with persistent activity of extracellular signal-regulated kinase or akt kinase pathways. Clin Cancer Res 9: 2316-2326, 2003.

38. Moasser MM, Basso A, Averbuch SD and Rosen N: The tyrosine kinase inhibitor ZD1839 ("Iressa") inhibits HER2-driven signaling and suppresses the growth of HER2-overexpressing tumor cells. Cancer Res 61: 7184-7188, 2001.

39. Normanno N, Campiglio M, De LA, Somenzi G, Maiello M, Ciardiello F, Gianni L, Salomon DS and Menard S: Cooperative inhibitory effect of ZD1839 (Iressa) in combination with trastuzumab (Herceptin) on human breast cancer cell growth. Ann Oncol 13: 65-72, 2002.

40. Bruns CJ, Solorzano CC, Harbison MT, Ozawa S, Tsan R, Fan D, Abbruzzese J, Traxler P, Buchdunger E, Radinsky R and Fidler IJ: Blockade of the epidermal growth factor receptor signaling by a novel tyrosine kinase inhibitor leads to apoptosis of endothelial cells and therapy of human pancreatic carcinoma. Cancer Res 60: 2926-2935, 2000 . 
41. Xia W, Mullin RJ, Keith BR, Liu LH, Ma H, Rusnak DW, Owens G, Alligood KJ and Spector NL: Anti-tumor activity of GW572016: a dual tyrosine kinase inhibitor blocks EGF activation of EGFR/erbB2 and downstream Erk1/2 and AKT pathways. Oncogene 21: 6255-6263, 2002.

42. Junttila TT, Laato M, Vahlberg T, Soderstrom KO, Visakorpi T, Isola $\mathbf{J}$ and Elenius $\mathrm{K}$ : Identification of patients with transitional cell carcinoma of the bladder overexpressing ErbB2, ErbB3, or specific ErbB4 isoforms: real-time reverse transcription-PCR analysis in estimation of ErbB receptor status from cancer patients. Clin Cancer Res 9: 5346-5357, 2003.

43. Srinivasan R, Poulsom R, Hurst HC and Gullick WJ: Expression of the c-erbB-4/HER4 protein and mRNA in normal human fetal and adult tissues and in a survey of nine solid tumour types. J Pathol 185: 236-245, 1998.

44. Rajkumar T, Gooden CS, Lemoine NR, Gullick WJ and Goden CS: Expression of the c-erbB-3 protein in gastrointestinal tract tumours determined by monoclonal antibody RTJ1. J Pathol 170: 271-278, 1993.

45. Issing WJ, Heppt WJ and Kastenbauer ER: erbB-3, a third member of the erbB/epidermal growth factor receptor gene family: its expression in head and neck cancer cell lines. Eur Arch Otorhinolaryngol 250: 392-395, 1993.
46. Earp HS III, Calvo BF and Sartor CI: The EGF receptor family-multiple roles in proliferation, differentiation, and neoplasia with an emphasis on HER4. Trans Am Clin Climatol Assoc 114: 315-333, 2003.

47. Tari AM and Lopez-Berestein G: Serum predominantly activates MAPK and akt kinases in EGFR- and ErbB2-overexpressing cells, respectively. Int J Cancer 86: 295-297, 2000.

48. Kaufmann SH and Earnshaw WC: Induction of apoptosis by cancer chemotherapy. Exp Cell Res 256: 42-49, 2000.

49. Schlessinger J: Common and distinct elements in cellular signaling via EGF and FGF receptors. Science 306: 1506-1507, 2004.

50. Allen LF, Lenehan PF, Eiseman IA, Elliott WL and Fry DW: Potential benefits of the irreversible pan-erbB inhibitor, CI1033, in the treatment of breast cancer. Semin Oncol 29: 11-21, 2002 .

51. Mendelsohn $\mathrm{J}$ and Baselga $\mathrm{J}$ : The EGF receptor family as targets for cancer therapy. Oncogene 19: 6550-6565, 2000.

52. Rao GS, Murray S and Ethier SP: Radiosensitization of human breast cancer cells by a novel ErbB family receptor tyrosine kinase inhibitor. Int J Radiat Oncol Biol Phys 48: 1519-1528, 2000 . 